\title{
EL HUMOR EN LOS DOMINICANOS COMO PRETEXTO DEL TRAUMA CULTURAL DE LA COLONIZACIÓN
}

\author{
Humor in the Dominicans as a pretext of the cultural trauma \\ of colonisation
}

\section{Patricia Liranzo}

Profesora del Área de Ciencias Sociales y Humanidades del Instituto Tecnológico de Santo Domingo (INTEC), Santo Domingo. ORCID: 0000-0002-4328-6008, Correo-e: patricia.liranzo@intec.edu.do

\section{Recibido: 24/9/2020 • Aprobado: 19/10/2020}

Cómo citar: Liranzo, P. (2020). El humor en los dominicanos como pretexto del trauma cultural de la colonización El humor en los dominicanos como pretexto del trauma cultural de la colonización. Ciencia y Sociedad, 45(4), 7-31. Doi: https://doi.org/10.22206/ cys.2020.v45i4.pp7-31

\section{Resumen}

En este articulo de reflexión se plantea que el humor en los dominicanos se ha convertido en una defensa patológica que permanece como una barrera que impide integrar las experiencias traumáticas, como fue la colonización. El enfoque es cualitativo con un diseño documental de tipo bibliográfico y argumentativo. La colonización significó un acontecimiento traumático que alteró la vida de los pueblos originarios con experiencias colectivas de abuso, muertes, malos tratos, trabajo forzado, hambrunas, epidemias, guerras, suicidios, un sistema esclavista despiadado y la pérdida cultural. La colonización se manifiesta como una herida enmascarada del trauma cultural que se afronta desde lo inconsciente a través de la figura del Trickster personaje universal que representa lo cómico. El Trickster dominicano, como figura daimónica, se polariza en la sombra, convirtiéndose en persecutor por medio del humor agresivo, que se manifiesta como una defensa inconsciente que pretende menospreciar y ridiculizar al otro. Este humor agresivo, espasmódico y seco es una forma de control compulsivo que se conoce como relajo. Es un Trickster que expresa la invisibilización de los grupos originarios, la desdicha de la herencia española, la tristeza del negro esclavo y todo el sufrimiento a posteriori de la

\begin{abstract}
This analytical article suggested that humor in Dominicans have become a pathological defense which remains like a barrier that prevents the integration of traumatic experiences during the colonization. The approach is qualitative with a bibliographic design and an augmentation documentary design. The Colonization meant a traumatic event that altered the lives of the island natives with experiences of abuse, deaths, mistreatments, forced labors, famines, epidemics, wars, suicides, a ruthless slave system and the loss of culture. Colonization manifests itself as a masked wound of cultural trauma that is faced from the unconscious through the figure of the trickster Universal character representing the comic. The Dominican Trickster, as a daemonic figure, is polarized in the shadow, becoming a persecutor through aggressive humor, which manifests itself as an unconscious defense that seeks to belittle and ridicule the other. This dry, jerky, aggressive mood is a form of compulsive control known as "Playing around". It is a Trickster that expresses the invisibility of the original groups, the misery of the Spanish heritage, the sadness of the black slave and all the post-colonization suffering in a partially incorporated racial and cultural mixture.
\end{abstract}


colonización en una mezcla racial y cultural parcialmente incorporada. El relajo del dominicano es una defensa inconsciente, que mantiene la estructura del trauma, por tanto, la fragmentación polarizada del self individual y colectivo, que no se integra a la vida consciente por lo tanto perdura como una continua disculpa del trauma histórico y cultural de la colonización.

Palabras clave: colonialidad; trauma cultural; opresión; psicología analítica; humor; arquetipos.

\section{Introducción}

El proceso de colonización en América constituyó un evento que alteró la dinámica y la vida de los pueblos originarios de este continente. Como sistema económico, político y social, implantado por los europeos, también produjo experiencias individuales y colectivas que, según Alegría, (en Robiou-Lamarche, 2016) para los pobladores originarios significó "abuso y atropello" (párr. 2) lo que tuvo como consecuencia una acelerada disgregación del grupo taíno, los pobladores que en su mayoría habitaban la isla.

Los procesos históricos anteriores a la colonización se caracterizaban por la interacción de distintas dinámicas que dificultaban demarcar las fronteras de lo que conforma el Caribe, ya que "no hay una definición correcta del Caribe" (Ulloa-Hung 2014, p. 27). Esta era la realidad cultural y social que existía a la llegada de los colonizadores.

Mira-Caballos (2017) hace referencia a la reducción de la población taína en América, y al referirse a las causas incluye las muertes y los malos tratos, el trabajo forzado que llevó a niveles altos de extenuación, el hambre, la propagación de enfermedades y el secuestro de las mujeres a gran escala durante los conflictos bélicos. "Se trataba de auténticos campos de concentración donde se imponía un trabajo forzado, que destruía su estructura social y que facilitaba la propagación de las enfermedades" (p. 315).
The "Playing around" of the Dominicans is an unconscious defense, which maintains the structure of the trauma; therefore, the polarized fragmentation of the individual and collective self, which is not integrated into conscious life. It also endures as a continuous apology of the historical and cultural trauma of the colonization.

Keywords: coloniality; cultural trauma; oppression; analytical psychology; humor; archetypes.

Por último, estaban las pocas ganas de vivir que llevaron a los indígenas a padecer depresiones y a manifestar tendencias suicidas. El resquebrajamiento de la estructura religiosa autóctona, que anteriormente servía de elemento unificador, condujo a los taínos a no querer vivir ese presente, lo que tuvo como efecto el 'desgano vital' (Mira-Caballos, 2017, p. 320): ya no les interesaba una actualidad como la que vivían, sino que su deseo era transcender para descansar en la eternidad junto a sus dioses, ancestros y el mundo perdido.

$\mathrm{Al}$ respecto, cabe afirmar que las experiencias vividas por los pobladores originarios de la isla $\mathrm{La}$ Española puede calificarse como de trauma histórico y cultural. Así lo afirman Kirmayer, Gone, y Moses (2014) debido a que implicó la opresión histórica y la supresión cultural de los pobladores indígenas.

De ese modo, la colonización y sus resultados en los pobladores taínos y caribes también significó un trauma cultural. Stamm, Stamm, H.E., Hudnall, y Higson-Smith (2004) explicaron que en el trauma cultural se produce una disrupción cuando la cultura original es expuesta a la cultura que llega. La intencionalidad o no de los efectos de este interjuego cultural puede tener consecuencias profundas y duraderas y, en algunos casos, redefinir a uno o ambos grupos. El resultado de esta redefinición varía en un rango desde el genocidio y la extensión cultural hasta una adaptación positiva que se denomina cambio cultural. 
La manifestación de un trauma histórico incluye sentimientos comunitarios o familiares de conmoción social, depresión existencial basada en la disrupción comunitaria, confusión con respecto a apropiarse del dolor ancestral, acompañado por la tentación de adoptar los valores coloniales. Además, se manifiesta duelo crónico existencial y angustia, que se exhiben en comportamientos destructivos. El trauma colonial diariamente se re-experimenta a través del racismo, los estereotipos y la falta de resolución del dolor comunitario (Stamm, et al., 2004).

El encuentro entre los nativos y los europeos asumió la forma de trauma y colapsó las sociedades preexistentes. Como consecuencia quedaron afectados los aspectos culturales, entre ellos profecías, ritos y creencias trascendentales, elementos constitutivos de su identidad a la llegada de los espańoles.

Estas heridas profundas se han mantenido abiertas a través de los siglos posteriores, al punto que pueden ser consideradas como la base de la identidad de las Américas y puede ser llamada a fusionarse o convertirse en un complejo cultural (Zoja, 2004).

Desde el enfoque de la Psicología Analítica, y de acuerdo con Singer (2002b en Weisstub \& Galili-Weisstub, 2004), los complejos individuales y los complejos culturales tienden a ser repetitivos, autónomos, resisten lo consciente y coleccionan experiencias que confirman su punto de vista histórico.

Cuando una persona o sociedad experimenta un trauma se activan en los individuos los mecanismos de defensa, que se definen como las estrategias para conservar el balance psicológico de forma inconsciente, para afrontar la ansiedad. Por un lado, estos pueden preservar a las personas de las agresiones del mundo exterior y, por el otro, pueden distorsionar la perspectiva de la realidad. Los mecanismos de defensa "protegen al yo 'rechazando' sentimientos de ansiedad y culpa” (Álava, \& Álava, JL, 2019, p. 8).
El humor está dentro de la categoría de las defensas más adaptativas y, según lo postulado por Freud (en Boerner, Joseph \& Murphy, 2017), el humor posibilita que la persona observe una realidad dolorosa con una actitud desafiante, de manera tal que se puede trascender y transformar el dolor y el estrés en algo incluso placentero.

Sin embargo, el humor es multidimensional y no todos los tipos de humor pudieran tener un potencial sentido de protección. El humor puede incluir elementos perjudiciales. Martin (en Boerner, et al., 2017) propone cuatro estilos de humor. El estilo de humor afiliativo, el humor de auto-mejora, el humor agresivo y el humor autodestructivo. Los dos primeros se consideran benignos y los dos últimos nocivos.

Argumenta Mandacarú-Guerra (2018) que la sombra de la historia del país, latente en la crisis que se vive, es externalizada en los chistes que revelan dolor, constatan prejuicios y debaten costumbres. Como conclusión, la risa se instala en vez del llanto. En ese sentido, "el dolor y la impotencia son dos sentimientos que se ocultan detrás del humor defensivo" (p. 3).

Ser la causa de la risa o broma, es decir, convertirse en alguien víctima de un intercambio donde prevalece el humor defensivo o cruel, produce en la persona sentimientos de deshonra, desprestigio y debilitamiento. Como respuesta ante esta dinámica, la persona asume una posición impasible o se identifica con el sujeto de burla, o se comporta de forma activa expresando agresión en la medida que la experimentó. Cuando las personas responden a situaciones muy difíciles o angustiantes con este tipo de humor, se puede decir que esto es una afirmación sombría (Mandacarú-Guerra, 2018).

A partir de lo expuesto anteriormente, podemos decir la tesis o hilo conductor de trabajo es que el humor en las dominicanas y en los dominicanos se ha convertido en una defensa patológica que 
permanece como una barrera que impide integrar las experiencias dolorosas y traumáticas, tal y como fue el proceso colonizador.

\section{Objetivos de investigación}

1. Describir los efectos de la colonización en los pobladores originarios y su desaparición física.

2. Indagar por qué la colonización es un trauma histórico y cultural.

3. Explorar la relación entre la colonización y la colonialidad del ser en las dominicanas y los dominicanos.

4. Analizar la estructura inconsciente daimónica del trauma cultural de la colonización en las dominicanas y los dominicanos.

5. Determinar el rol defensivo del humor en la experiencia traumática.

\section{Metodología}

El enfoque de esta investigación es cualitativo y está orientada a la indagación de temas relevantes a través de una estructura en espiral, donde las preguntas o hipótesis de trabajo se pueden realizar antes, durante y después de la recolección y análisis de los datos.

El tipo de investigación es documental. Donde se pretende comprender un fenómeno o problema y aportar en la construcción de conocimiento por medio de documentos escritos, fuentes de información impresa y digital, contenidos y referencias bibliográficas.

A su vez, esta investigación documental es de carácter bibliográfico y argumentativo en tanto se aspira registrar información bibliográfica de diversas fuentes primarias y secundarias y realizar reflexiones para darle respuesta a las preguntas de investigación y objetivos de trabajo. La técnica de la recolección de los datos que se utilizan la interpretación y el análisis de contenido.

Esta reflexión significa una innovación y aporte para la compresión del imaginario individual y colectivo dominicano con una mirada transdisciplinar desde lo histórico, ontológico, psicológico y filosófico. Se basa en un análisis amplio que incluye lo individual como puente hacia lo grupal visto en la conjugación de diversos marcos de referencias teóricos, lo que posibilita atravesar las disciplinas y acercase a la experiencia integral y compleja de las personas y las comunidades

\section{Población originaria del Caribe}

Anterior al arribo de los españoles, en la isla Bohío, luego La Española, y en todas las Antillas existían diversos grupos culturales provenientes del continente, a lo largo de miles de años. Alegría agrupa, para este momento histórico, la existencia de tres complejos culturales: Arcaicos, Arahuacos y Caribes (en Robiou-Lamarche, 2016).

Entre los Arahuacos se encontraban los taínos que eran mayoría, así como los macorixes, los ciguayos y los siboneyes. Inoa (2018) postula que los pobladores de la isla eran heterogéneos y con expresiones lingüísticas distintas. En la isla no predominaba ningún patrón cultural, sino que existía una multiplicidad de manifestaciones culturales.

En ese sentido, al referirse al Caribe precolombino, Ulloa-Hung (2014) expresa que el mismo estaba matizado de un dinamismo significativo donde se enlazaron procesos históricos complejos, con migraciones, enfrentamientos, encuentros y convergencia de paisajes y tierras, entre grupos humanos con variados orígenes que generaron sociedades con una marcada geopolítica externa. Los investigadores sobre esa época utilizaron las fuentes o documentos de los colonizadores para estudiar la época precolonial, lo que hizo que se homogenizaran características, conceptos y términos culturales de los grupos que habitaban el Caribe. 
La visión de los caribes, recopilada en varios documentos históricos, produjo la primera perspectiva dicotómica de las culturas antillanas indígenas. Por un lado, se encontraban los pobladores obedientes y con disposición para 'ser civilizados' (UlloaHung, 2014, p. 51). A estos se les designaba como los no caribes. Por el otro lado, estaban los habitantes más subversivos, inhumanos y sanguinarios, los caribes, ubicados en la parte oriental de las islas.

Las semejanzas y diferencias de estos grupos no se suscitaron por un ancestro común, sino por el intercambio entre el conjunto de individuos con diversos orígenes culturales. Este intercambio dinámico permaneció durante siglos y generó diversos reservorios simbólicos que fueron compartidos, aunque de forma incompleta, por la pluralidad de tales sociedades y empleados, pero en diferentes versiones, por todo el archipiélago y la historia (Curet, 2014).

\section{Efectos de la colonización en la isla}

El proceso colonizador que implantó Colón, y que continuaron sus sucesores, estuvo fundamentado tanto en las excursiones para la búsqueda del oro como en la obligación del pago de tributos a las zonas que eran dominadas. El patrón de la estructura colonial implicó la captura de indígenas para enviarlos como esclavos a Europa y la instauración en la isla de un sistema esclavista disfrazado con un proceso denominado las encomiendas.

Cassá (1974) alega que la causa principal de la muerte de los taínos fue el trabajo forzado demandado por la encomienda, más que las epidemias, hambrunas, guerras o suicidios.

La encomienda como estructura se basó en el sistema feudal español que al ser aplicado en el continente recién descubierto adquirió unos matices diferentes. Fue el cimiento de un sistema esclavista despiadado, en el que la explotación de la mano de obra alcanzó grados de intensidad hasta el momento no conocidos (Cassá, 1974). La encomienda fue el modo empleado por la corona espańola para garantizar el control absoluto y la colonización de las nuevas tierras.

Los hombres y las mujeres indígenas fueron perjudicados por el régimen de repartimientos, puesto que eran trasladados a localidades alejadas de sus comunidades, lo que producía una interrupción completa del vínculo con la vida acostumbrada del poblado (Domínguez, 2006).

Luego se implantó el esquema de demoras, el que consistió en ampliar los meses de trabajo y la readjudicación de los repartimientos. Esto trajo como efecto una explotación escandalosa, cuya demostración más relevante fue el exterminio físico de los indígenas y la destrucción de las estructuras sociales y culturales de estos (Domínguez, 2006).

La existencia de los indígenas se caracterizaba por inhumanos maltratos y por los constantes desprecios a los que eran sometidos, generándoles estados depresivos. Las prácticas fundamentales utilizadas por los indígenas para su conservación estaban prohibidas. No podían realizar areitos, ni jugar a la pelota, ni aspirar cohoba, ni asearse en los meses de trabajo. Esta restricción de sus aspectos culturales y religiosos afectaba de manera significativa el equilibrio físico, [emocional] y cultural en que se fundamentaban las comunidades taínas (Cassá, 1974).

En esta misma época se comenzó a impulsar el cultivo de la cańa para sustituir la economía basada en el oro, que había sido un fracaso. Esta actividad se topó con muchas dificultades para conseguir mano de obra, pues para esta época la población indígena ya había disminuido de manera impresionante. Por ello, en 1518 los padres Jerónimos solicitaron al rey licencia para importar esclavos hacia La Española. Sin embargo, los negros habían sido introducidos en la isla por Ovando en el año 1502 (Inoa, 2018). 
La colonización se caracterizó además por la transculturación. Algunos elementos de la cultura material indígena se traspasaron a los españoles, y luego a los negros esclavos, de tal modo que contribuyeron a la formación de la sociedad colonial (Cassá, 1974).

También se dio el trato sexual de las mujeres indígenas con españoles y con negros generando así un mestizaje físico y cultural. Las uniones en el principio entre indígenas y españoles tenían un carácter voluntario, pues las mujeres taínas eran objetos de intercambio; pero esta situación fue modificándose drásticamente hasta conducir a relaciones sistemáticas de coerción (Cassá, 1974).

De igual forma, otras de las configuraciones culturales más importantes de la sociedad colonial fueron el vínculo e intercambio sexual entre las indígenas y los esclavos negros (Cassá, 1974). Posteriormente, según Inoa (2018) los esclavos cimarrones se robaban a las taínas para adjudicarlas como sus mujeres en sus grupos. El elemento de coerción se mantenía de forma parcial. La unión entre indígenas y esclavos negros generó afiliaciones recíprocas de manifestaciones culturales que solo permanecieron de los indígenas a los negros, en razón de la desaparición de los primeros (Cassá, 1974).

Para la cultura taína el cambio social que implicó la colonización, y que estuvo determinada por la subyugación de las comunidades originarias, generó una masacre física paulatina y el dominio y la desarticulación de las instituciones sociales de los pobladores (Cassá, 1974).

Por consiguiente, la colonización como experiencia de vida que aconteció a los habitantes originarios de la isla Bohío, luego La Española y de todas las Antillas, fue un conjunto de eventos, traumáticos, que modificaron estructuralmente, tanto en lo colectivo como en lo individual, a las diversas culturas y grupos sociales que poblaban las Antillas.

\section{Relación entre la colonización y la colonialidad de ser}

La colonización fue un acontecimiento que en su forma concreta negó la consideración de los indígenas como grupos sociales que pudieran ser conocidos o comprendidos como seres humanos, como personas, en su historia, en su esquema social y cultural; eran considerados, más bien, como carentes de racionalidad, como no humanos. Esta manera de pensar conduce a lo que se conoce como colonialidad (Gómez-Quintero, 2010).

Los colonizadores instauraron un nuevo modo de relación, en el que los vínculos intersubjetivos estaban basados en el esquema de dominación de Europa y de lo europeo sobre las otras regiones y localidades del mundo, a las que se les imponían, quisieran o no, nuevas identidades geoculturales (Quijano, 2014).

El sometimiento en esta área estuvo caracterizado por una acción profunda, firme y agresiva que condenó a los indígenas de la América ibérica a convertirse en una subcultura rural, ignorante, privándolos de su herencia intelectual objetiva (Quijano, 2014).

Los procesos de colonialidad incluyen no solo los relativos al poder y al saber, sino también al ser. De acuerdo a Castro (2007) la concepción del ser, desde la perspectiva eurocéntrica, plantea a un ser no enunciado, no situado, sin cuerpo, y universal, pero que en el ámbito práctico responde al patrón europeo no solo en el aspecto físico, sino en lo relativo a sus costumbres, expresiones culturales y a su manera de vivir y entender el mundo

Maldonado-Torres (2007) recreando a Fanon, explica la colonialidad del ser a partir del misterio de lo negro, que el autor refiere como el elemento inicial para reflexionar acerca de la misma y, para comprenderla, es preciso revisar las vivencias de los individuos negros colonizados. Fanon los describió como los damnés o los castigados de la tierra. 
En el universo colonial, las muertes y las violaciones acontecían como sucesos peligrosos y cotidianos, tal como sucede en la guerra. A su vez, estos dańos al cuerpo se convierten en la imagen que representa al hombre y a la mujer colonizados. La colonialidad del ser entonces se convierte en la normalización de las circunstancias excepcionales de una guerra (Maldonado-Torres, 2007).

La colonialidad del ser es considerada como la violación del sentido del otro humano, a tal grado que ese alter-ego se convierte en un sub-alter. En otras palabras, el otro diferenciado es categorizado como otro inferior (Maldonado-Torres, 2007). Como resultado: "Esta estructura triangular de la colonialidad es lo que Maldonado ha denominado la colonialidad del ser" (Castro, 2007, p. 140).

La colonialidad está presente en el imaginario individual y colectivo dominicano indica algunas características entre las que se encuentran: pasividad, minusvaloración como pueblo, violencia, despotismo, autoritarismo, la falta de confianza en nosotros mismos, imitación y preferencia de lo extranjero, la pereza para la tarea del pensar y el paternalismo

La colonialidad de ser se refleja en las dominicanas y en los dominicanos, tanto en el ámbito particular como en el grupal, la idea de que la persona sea y se haga responsable de sus actos o por lo menos de qué hacer cuando aparezca un conflicto o problema refleja una dificultad en ser el "gestor de su propio bienestar y felicidad” (Minaya, 2014, p. 224).

\section{La mirada psicológica en el trauma}

Los individuos de manera particular y los grupos sociales al vivir un acontecimiento traumático experimentan consecuencias significativas que impactan el devenir personal y colectivo del ser humano. El trauma es una experiencia que puede ser personal pero también de carácter comunal.
El trauma, según Paivio y Pascual-Leone (2010), es una experiencia actual de amenaza o percepción de una amenaza de muerte, daño físico a la persona, a otros o a la integridad de sí mismo que incluye reacciones de terror, horror o indefensión.

El factor universal del trauma psicológico es el miedo intenso que padece la persona, así como desamparo, pérdida de control y peligro de aniquilación. En ese sentido, se plantea que los eventos traumáticos eliminan los factores y esquemas de protección normales que provocan, en los seres humanos, un sentido de dominio, conexión y significado (Saldaña, 2014).

La colonización se considera como un trauma complejo interpersonal, puesto que se refiere a una exposición repetida a amenazas de violencia que incluye lo social, la violencia política a través de la guerra o la tortura, la violencia doméstica ya sea como víctima o como testigo y el abuso o maltrato infantil (Paivio y Pascual-Leone, 2010).

El trauma complejo que puede padecer un individuo implica la exposición continua de la persona a entornos traumatizantes a través de un amplio periodo de tiempo, lo que resulta en una agudización del daño psíquico y de las manifestaciones de los síntomas asociados (Nieto y López, 2016).

Freud clasifica los efectos del trauma en dos categorías: los positivos, que se refieren a manifestar en las relaciones actuales la herida original, el hecho traumático, reexperimentándolo para hacerlo real. Estos evidencian la compulsión a la repetición de la situación traumática y su fijación (Etchegoyen et al., 2005). Y los negativos, que son opuestos a los primeros, se encuentran inhibidos, su existencia no se reconoce, hay un desconocimiento del recuerdo traumático. En la evasión se consolidan las defensas y cuando el yo no puede evitar su manifestación se traduce en síntomas, inhibiciones o fobias (Etchegoyen et al., 2005, p. 213). 


\section{El trauma desde la perspectiva analítica}

Jung con respecto al trauma indicó que una reacción esperada es que la persona se separe del contexto o escena donde existe el daño o la herida, pues si esto no fuere posible el yo se divide en pedazos o se disocia. La disociación implica la escisión de la experiencia donde a los elementos que normalmente se encuentran unificados en la consciencia, como consciencia cognitiva, afectos, sensaciones, imágenes, no se les permite integrarse (Kalsched, 1996).

La experiencia en sí se vuelve discontinua y las imágenes mentales pueden alejarse de los afectos o ambos; sentimientos e imágenes logran disociarse del conocimiento consciente. La sensación de recuerdos recurrentes parece desconectada del contexto donde el comportamiento ocurre. La memoria en la vida de la persona tiene agujeros, de ahí que la narrativa completa de la historia no puede ser comunicada por la persona cuya vida ha sido interrumpida por el trauma (Kalsched, 1996).

Para el individuo que ha padecido un dolor insoportable, la defensa psicológica de la disociación permite que la vida externa continúe, pero a un alto costo de la vida interna. El trauma exterior termina, pero sus efectos no pueden ser olvidados. Las secuelas psicológicas del trauma se mantienen persiguiendo el mundo interno de la persona (Kalsched, 1996).

\section{La forma daimónica del trauma}

Freud verificó que tanto en el proceso analítico como fuera de él, las personas que han sufrido trauma parecían estar atrapadas en repeticiones compulsivas de comportamientos autodestructivos, una especie de malestar que los hace parecer determinados a un destino negativo, a esto Freud le denominó compulsión a la repetición (Kalsched, 1996).
Para Jung, el nivel más grave del trauma lleva a una rigurosa fragmentación de las defensas primitivas del yo y la posesión en la personalidad de una imagen daimónica que proviene de la psique colectiva (Kalsched, 1996).

El espíritu de posesión de los complejos colectivos, según Jung, es precisamente una figura daimónica que sirve como un agente que es, a la vez, persecutorio y protector del sistema de autocuidado. El agente proviene del nivel más arcaico de la psique, por lo tanto, es extrańo y aterrador para el $y o$, lo que consigue que el yo ceda fácilmente su poder al complejo (Kalsched, 1996).

Los individuos que han padecido experiencias traumáticas infantiles tienen, a menudo, sensibilidades inusuales que los impulsan hacia su interior. Ese mundo interno al que se retiran se caracteriza por ser un santuario infantil de inocencia. Estos pacientes se aferran al remanente de esa experiencia de su infancia que había sido mágica y sustentadora en un momento, pero con un tinte de nostalgia y melancolía, que no creció junto con el resto de ellos. De ahí que una parte de la persona desea el cambio y otra parte, que es muy fuerte, resiste dicho cambio.

Kalsched (1996) es un analista y autor que ha profundizado en el estudio y análisis de los sueños. En ese sentido, este afirma que en los sueños de estas personas aparece una figura que es una fuerza tan poderosa que el concepto daimónico parece ser el más apropiado para referirse a dicha figura.

En un momento, la meta de esa figura parece ser la encapsulación de alguna parte frágil o vulnerable de la persona, la cual es despiadadamente separada de la realidad como una manera de evitar ser violentada otra vez. En otro momento, el ser daimónico es una especie de ángel guardián, que calma y protege internamente una parte infantil del self y al mismo tiempo la oculta vergonzosamente del 
mundo. El daimón podría desempeñar un papel protector o persecutorio, alternando algunas veces entre ambos. Esa imagen dual se activa manifestándose a menudo como negativo y merece la persecución, por así decirlo, y en otras ocasiones como positiva, por lo que recibe protección.

Estas imágenes duales se unifican y conforman una estructura interna que el autor denominó sistema de autocuidado arquetípico. Esta estructura, postula Kalsched (1996), es un sistema universal interno de la psique, cuyo rol parece ser la defensa y preservación de un espíritu personal inviolable en el núcleo del verdadero self de un individuo.

La psique no puede simbolizar algo inaguantable hasta mucho tiempo después, lentamente el acontecimiento traumático puede ser dicho y vuelto a decir, entonces los sueños comienzan a simbolizar la experiencia hasta que eventualmente es metabolizada. Sin embargo, en el trauma infantil que es insoportable y prolongado, el sistema de defensa arcaico aparece con la capacidad de destruir el mundo interno psicológico. La experiencia se vuelve sin sentido, tanto los pensamientos como las imágenes, están desconectadas de los afectos.

El sistema de autocuidado lleva a cabo sus funciones por medio de arremeter activamente contra los elementos que asume como extraños o peligrosos. Las partes de la experiencia self que han sido vulneradas por el trauma en realidad han sido vistas como componentes tan peligrosos que, en consecuencia, son atacadas. Estas agresiones sirven para socavar la esperanza en una relación objetal real y conducir a la persona más profundamente dentro de su fantasía. Así como el sistema inmunológico puede ser engańado para agredir la vida misma que está tratando de proteger, como una enfermedad autoinmune, así el sistema de autocuidado puede convertirse en un sistema auto-destructivo, el cual vuelve el mundo interno de la persona en una pesadilla de persecución y auto-agresión.

\section{La colonización como trauma histórico y cultural}

Se ha propuesto que el proceso colonizador ha sido una forma de genocidio que ha causado variadas manifestaciones del estrés postraumático, similar al exterminio experimentado por los judíos en el holocausto (Duran \& Duran, E., 1995; Mitchell \& Maracle, 2005 en Hawkeye, 2015).

Duran, B., Duran E., y Yellow Horse Brave Heart, (1998) indicaron que una de las consecuencias del proceso colonizador en América fue el genocidio cultural, el cual se manifestó de distintos modos. La prohibición de la libertad de religiones [como ejemplo, a los taínos se les impidió celebrar areítos, jugar pelota o inhalar cohoba (en Cassá, 1974)], constituye una práctica concreta de eliminación de prácticas culturales, que pervivieron en los nativos americanos hasta el año 1978. En el caso dominicano, hubo una mezcla con la cultura de los africanos que llegaron a la isla, generando así un sincretismo cultural.

Se puede afirmar que la colonización significó un proceso de traumatización extrema, ya que existe la dificultad de admitir la violencia ejecutada, la amenaza de muerte duradera en el tiempo y que trasciende el evento traumático. Esto genera que el suceso traumático extremo se contenga y emerja en el presente de los grupos sociales. En la no admisión de la herida provocada por el trauma se obstaculiza el desarrollo de una subjetividad, que tiene como consecuencia que la persona ejerza un sometimiento del otro u otros, convirtiéndose en la única forma de relacionamiento con los demás (Gómez, 2016).

El trauma cultural ocurre cuando los miembros de una colectividad sienten que han sido sometidos a un evento horrendo que deja marcas indelebles en su conciencia colectiva, marcando sus recuerdos para siempre y cambiando su identidad de manera 
fundamental e irrevocable (Alexander, 2016, p. 4). Es decir, el trauma pervive a lo largo del tiempo en las distintas generaciones posteriores.

Weisstub y Galili-Weisstub (2004) explican que un trauma repetitivo hacia un grupo de personas resulta en la creación de complejos culturales, que a su vez alimentan más eventos traumáticos. El trauma es un círculo vicioso que conduce a un trauma complejo. Cuanto más se precipita el trauma más se refuerza el complejo de manera ineludible, en una progresión en cascadas que es destructiva.

Los complejos culturales se fundamentan en vivencias históricas reiteradas que se han fijado y hasta naturalizado en la psique colectiva de las comunidades y en la psique de los individuos que son parte del grupo y que, además, exteriorizan valores arquetípicos para el grupo. Los complejos culturales pueden entenderse como estructuras que cimientan una sociología dentro de los grupos (Singer, 2006).

Los complejos culturales, a su vez, tienden a ser polarizados; es decir, al activarse, el yo se identifica con una parte del complejo inconsciente, mientras la otra parte es proyectada fuera sobre otro grupo.

Singer (en Weisstub \& Galili-Weisstub, 2004) ha identificado tres componentes de este particular tipo de complejo cultural que se activa cuando el espíritu del grupo se ve amenazado. Estos son:

a) Lesiones traumáticas en personas vulnerables, grupo de personas, lugares o valores que sostienen el espíritu de grupo.

b) Miedo de ser aniquilado por el otro foráneo, tanto en lo personal como en el espíritu de grupo.

c) Emergencia de defensas tipo protector/perseguidor vengativo dentro del espíritu del grupo.
Cuando los complejos culturales permanecen en el tiempo se genera una incapacidad para que la colectividad pueda lamentar la pérdida de personas, prácticas sociales y culturales (Weisstub \& Galili-Weisstub, 2004).

Los complejos culturales pueden ejercer su poder por siglos. Singer se ha referido a las defensas arquetípicas colectivas las cuales son activadas en respuesta a una herida traumática de un ser divino que representa el espíritu del grupo. El autor asocia el surgimiento de esas defensas con el miedo a la aniquilación del espíritu grupal. Las defensas arquetípicas sirven para proteger al grupo cultural de la experiencia de pérdida (Weisstub \& Galili-Weisstub, 2004).

El trauma cultural como experiencia colectiva se basa en un esquema de poder con dos polaridades, el opresor y el oprimido; para el caso presente, los colonizadores como los opresores y los indígenas de La Espańola como los oprimidos.

\section{Panorama de la opresión}

El proceso de ejecutar o recrear la opresión puede manifestarse a través de la imposición y privación. De acuerdo con Hanna, Talley y Guindon (2000) (en David y Derthic, 2018) la opresión por imposición o fuerza es la acción de obligar a otros a una etiqueta, una experiencia de rol, o a un conjunto de requisitos de vida que no son deseados, los cuales son innecesariamente dolorosos y que reducen el bienestar físico o psicológico.

La opresión provoca la diferenciación de los individuos en grupos categorizados como: dominante-dominado, opresor-oprimido. En ese sentido, la pertenencia a un grupo particular determina la magnitud del poder al que accede la persona o la oportunidad y la capacidad de acceder a los recursos (David y Derthic, 2014).

A su vez, estas posiciones de poder a menudo se utilizan para degradar la cosmovisión indígena, su 
conocimiento y sus destrezas, mientras se difunde y propaga una percepción pública distorsionada y deshumanizadora de su cultura que opera para mantener subyugados los pueblos indígenas que todavía perviven en la región (David y Derthic, 2018).

Aún más, la opresión también puede ser representada por la privación, como cuando los colonizadores despojaron a los pueblos indígenas del derecho a gobernarse a sí mismos; limitaron el poder del gobierno tribal indígena, básicamente tratando a las personas indígenas como menos merecedoras de lo que se les permitía a los colonizadores (David y Derthic, 2018).

Cuando a los individuos se les hace difícil reconocer y confrontar el origen de la opresión, la rabia experimentada puede ser dirigida hacia el interior y hacia otros que les recuerdan lo oprimido en sí mismos, condición que se denomina opresión internalizada (David y Derthic, 2018). Pyke (2010) indica que la opresión internalizada es una herida encubierta que es frecuentemente ignorada o minimizada (en David y Derthic, 2014).

Existe una relación estrecha entre el proceso colonizador, la opresión y la opresión internalizada. Este vínculo se explica a partir del modelo colonial de las cuatro fases de Fanon (1965) (citado en David y Derthic, 2014), que es un marco de referencia clásico para comprender el fenómeno de la opresión y la opresión internalizada:

- La primera fase del proceso colonizador fue la entrada impuesta de un grupo extranjero en un territorio para explotar sus recursos naturales, incluidos sus habitantes.

- La segunda fase consiste en la implantación de la cultura del colonizador que desintegra la cultura indígena y rehace esa misma cultura indígena a partir del modo en que la define el colonizador.
- En la tercera etapa las personas indígenas eran presentadas como salvajes e incivilizados a quienes el colonizador, noblemente, debía controlar, domesticar y educar. Así, la tercera fase transmite tiranía y dominación $y$, por tanto, la opresión se hacía necesaria.

- Finalmente, la cuarta fase consiste en el establecimiento de una sociedad donde las instituciones políticas, económicas y sociales estaban diseñadas para beneficiar y mantener la superioridad del colonizador, mientras que, paralelamente, subyugaban a los indígenas colonizados. Esta cuarta fase puede verificarse en las instituciones erigidas en las regiones colonizadas, que recompensan a los que se asimilaban a las formas del colonizador, mientras castigaban a quienes no lo hacían.

Los contextos opresores descritos influyen en las personas oprimidas. Los académicos postcoloniales argumentan que la opresión internalizada, de manera específica el colonialismo internalizado, es la principal consecuencia del proceso colonizador. Fanon explica que la sostenida denigración e injusticia que sufrieron los indígenas lleva a la duda, a la confusión en la identidad y a sentimientos de inferioridad entre los colonizados (David y Derthic, 2014).

A pesar de que los siglos han pasado, los valores eurocéntricos continúan permeando América del Norte, América del Sur y el Caribe [mayor y menor]. El culturalismo único eurocéntrico todavía en la actualidad contamina la mente de latinos y latinas provocando en ellos el cuestionamiento de su valor propio y del valor de su herencia cultural (Hipólito-Delgado, Gallegos y Baca, 2014).

Carvallo (2012) postula que Latinoamérica es una región divida por sus complejos culturales. En ese sentido, explica que las sociedades latinoamericanas se encuentran estructuradas en un rígido sistema de clases establecido a partir del primer 
encuentro entre los conquistadores europeos y la población indígena que habitaba el territorio. Este enfrentamiento está profundamente arraigado en el inconsciente cultural de la región, el cual tiende a ser ignorado a nivel individual consciente entre la mayoría de los latinoamericanos.

Este trauma profundo forma un núcleo regresivo en la estructura de la psique de América Latina que debe considerarse en cualquier intento para comprender los síntomas y la manifestación de los complejos culturales de la región (Carvallo, 2012).

La característica esencial que define la estructura arquetípica de la colonización española fue un rígido patrón de autoritarismo dentro de un estricto monoteísmo que contrastaba marcadamente con el marco arquetípico entre los pueblos indígenas, que incluía un equilibrio entre las fuerzas masculinas y femeninas y una estrecha relación de mutualidad entre las comunidades indígenas y el entorno natural (Carvallo, 2012).

Dos tendencias interconectadas se reflejan en las actitudes que emergen de los tiempos coloniales: el otro lado y la invisibilización. El otro lado se refiere a la situación indígena en América, con respecto al intento de los ganadores del conflicto cultural de eliminar a esos otros. Despojados de sus símbolos y rituales y coaccionados a aceptar mitos extranjeros sobre las creencias esenciales acerca de la creación y de las fuerzas que gobiernan la vida, estas personas conquistadas parecían condenadas a muerte, en ambas formas, literal y simbólica. Es fácil darse cuenta de cómo los colonizados sucumbieron al instinto de muerte, Tanahtos.

La invisibilización es el segundo gran efecto de la conquista: los vencedores hicieron todo lo posible por hacer invisible la cultura de los colonizados. Ese proceso de invisibilización fue acompañado, en parte, por políticas gubernamentales que solo beneficiaban a un sector de la población, los colo- nizadores. Este método de gobernar fue significativo en la colonización hispano-americana, ya que el gobierno oficial sistemáticamente excluía y trataba a los indígenas como personas de segunda categoría. Lo que Carvallo (2012) denomina invisibilización puede bien ser el equivalente al mecanismo de defensa de la negación, el cual es conocido muy bien en la psicología del individuo.

Cabe destacar que la mezcla de sangre, genes, costumbres, rituales e imágenes del Otro conquistado, los indígenas de América, se deslizó en la psique cultural a pesar de los esfuerzos de los españoles por eliminarlos. Este deslizarse a través del inconsciente cultural de los elementos prehispánicos de la cultura nativa contribuyó a la formación de complejos culturales que reflejan la dramática contradicción, en muchos aspectos, de la región latinoamericana contemporánea.

\section{Rol defensivo del humor en el trauma}

Platón y Aristóteles explican que el humor tiene un carácter infame y agresivo cuando tiene un objetivo concreto e identificado; estos planteamientos son semejantes a las teorías posteriores del humor hostil. No obstante, ambos filósofos dejan entrever que hay una diferencia entre la variante agresiva y la variante mitigada del humor (Schere, 2017).

La teoría del alivio del humor, se enfoca en que la risa tiene la función de atenuar una experiencia, siendo la risa una válvula de escape. La risa es indispensable para el cuerpo debido a que descarga tensiones. Poder liberar la sensación de nerviosismo o presión es causa de placer. El representante por excelencia y quien más aportó a la sistematización de la teoría del humor fue Sigmund Freud (Veira, 2018).

El chiste y su relación con el inconsciente ha sido identificado como un componente del lenguaje inconsciente. Freud señaló la contraposición entre el significado apropiado y lo absurdo, entre la unión de representaciones contrastantes y la presencia 
de asombro, en el origen de la risa. Las pulsiones libidinales y agresivas que son reprimidas en el inconsciente debido a su contenido inaceptable, se recuperan a través del chiste, lo que permite a la mente comunicar aquello que no se puede expresar por medio a la lingüística, semántica y a los artificios conceptuales (Amici, 2019).

El chiste según Veira (2018) tiene un componente social ya que permite una descarga de la desigualdad experimentada, así como de la injusticia social. El chiste posibilita la expresión de hostilidad contra las personas en posiciones de autoridad. El chiste desde este planteamiento representa una crítica de la estructura social desigual.

Desde la perspectiva psicológica, el humor se define como la tendencia a vivir o reflejar lo que es gracioso o divertido y se manifiesta con reacciones emocionales y conductas vocales, como la sonrisa y la risa. El humor parece estar presente en las diversas culturas humanas; no obstante, los individuos de distintos contextos pueden percibir el humor de diferentes modos (Jiang, Hao y Hou, 2019).

El sentido del humor puede conceptualizarse como: 1) una capacidad cognitiva, es decir, la destreza para crear, entender, contar y recordar chistes; 2) una disposición estética que se evidencia en la capacidad de apreciar el humor y sus variantes; 3) un patrón usual de comportamiento como la inclinación a reír con frecuencia, hacer chistes y entretener a otros, así como poder reírse de los demás; 4) un rasgo del temperamento que se encuentra vinculado a una emoción, como la alegría; 5) una actitud, es decir, la disposición hacia valorar lo externo de forma positiva; y 6) una estrategia de afrontamiento o mecanismo de defensa que se manifiesta en la inclinación a tener un visión humorística frente a los conflictos de la vida (Martin, Puhlik-Doris, Larsen, Gray y Weir, 2003). En síntesis, existen: a) Humor afiliativo. Las personas de esta dimensión tienden a ser divertidas, contar chistes y comprometerse a divertir a otros por medio de bromas ingeniosas y espontáneas, lo que facilita las relaciones y disminuye las tensiones interpersonales. Este estilo de humor se asocia a personas extrovertidas, alegres, con una autoestima estable, con satisfacción en la relación, y estados de ánimo y emociones positivas.

b) Humor auto-afirmativo. Esta categoría implica una perspectiva generalmente humorística de la vida, con una inclinación a divertirse con frecuencia por las incongruencias de la vida y a mantener dicha perspectiva frente al estrés o al infortunio. Es un tipo de humor vinculado a la regulación de las emociones y como estrategia de afrontamiento. Es el de mayor coincidencia con la definición de Freud (1928) del humor, en el sentido estrecho, como un mecanismo de defensa saludable que le permite a uno eludir las emociones negativas, desde una perspectiva realista, sobre una situación potencialmente aversiva.

c) Humor agresivo. Se expresa por medio del sarcasmo, hacer burlas, poner en ridículo, por provocar, denigrar y menospreciar. Este humor incorpora la manipulación de las personas a través de una amenaza tácita para poner en ridículo al otro. Es un tipo de humor compulsivo, donde la persona no resiste la urgencia de expresar algo gracioso a expensas de que pueda alterar o dañar a otro. Esta dimensión del humor se asocia de forma positiva con el neuroticismo y particularmente con la hostilidad, la ira y la agresión. En cambio, se relaciona de forma negativa con la satisfacción en la relación, la amabilidad y la consciencia.

d) Humor auto-destructivo. Esta dimensión se caracteriza por un humor excesivamente auto-peyorativo que se propone divertir a los otros al 
enfocarse en decir y hacer chistes o acciones graciosas para conseguir la atención de los demás u obtener su reconocimiento a expensas de sí mismo (Martin et al., 2003).

Con respecto a la posible relación entre el humor y el trauma hay estudios del campo de la psicología que plantean que el humor, por lo menos en sus manifestaciones benignas, puede funcionar como un recurso interior para los sobrevivientes de trauma, debido a que proporciona cierto grado de protección frente a la experiencia de angustia psicológica. Además, estas formas benignas del humor (humor afliativo y humor auto-afirmativo) pueden desempeñar funciones interpersonales importantes (Besser, Weinberg, Zeigler-Hill, Ataria y Neria, 2015).

La utilización del humor auto-afirmativo por los sobrevivientes de trauma muestra la disposición de mantener una perspectiva humorística frente a la adversidad y pueden transmitir resiliencia y una regulación positiva de las emociones (Besser, et al., 2015).

Los sobrevivientes de eventos traumáticos que emplean el humor auto-afirmativo se desempeñan de modo más eficaz frente a las consecuencias del trauma vivido y tienden a exhibir una perspectiva más positiva frente a la vida después del acontecimiento traumático (Besser et al., 2015).

El humor auto-destructivo se vinculó de manera positiva con los cambios negativos que siguen a las experiencias adversas, los estados evasivos y los problemas de regulación de las emociones. Estos resultados están alineados con los estudios realizados por Edwards y Martin (2010) y Erickson y Feldstein (2007), (citados en Boerner, Joseph y Murphy, 2017) quienes encontraron una asociación positiva entre el humor auto-destructivo y síntomas depresivos. En contraste con el humor auto-destructivo, que puede ser una forma de escapar o negar sentimientos incómodos, el humor agresivo puede ser más bien un instrumento para ganar poder dentro de un contexto social.

Maser y Cloninger (1990) indicaron que los mecanismos de defensa son procesos psicológicos cuyo fin es la protección del individuo y que le permiten a este manejar las amenazas externas, así como las dificultades internas que producen problemas. Baumeister, Dale y Sommer (1998) expusieron "que la función de los mecanismos de defensa es mantener y proteger el self de los conflictos internos y externos que pueden amenazar y dañar la percepción positiva del self" (citados en Galor y Hentschel, 2013, p. 120).

Estos mecanismos fomentan el bienestar psicológico, aumentan la disposición a la adaptación y permiten un desarrollo psicológico normal, además de que propician la propia coherencia, ya que disminuyen, modifican y desvirtúan la consciencia misma con relación a las percepciones, pensamientos, anhelos y afectos perturbadores. Estas resistencias tienen una tarea dual. Por un lado, defienden y amparan al yo de las pulsiones despreciables y, por el otro, hallan el modo de manifestar el mismo impulso indeseable facilitándole al yo un cierto nivel de gratificación (Galor y Hentschel, 2013).

La perspectiva psicodinámica reconoce que la conformidad de las defensas usadas permite la desaparición o la prolongación de la sintomatología de trastornos psicológicos. Los mecanismos de defensas más adaptativos son la supresión, la sublimación, el altruismo, la anticipación y el humor (Galor y Hentschel, 2013).

La aparición de las defensas está incluida en el funcionamiento normal, pero se valoran como patológicas cuando son empleadas de modo inadecuado, expresan una gran intensidad, su manifestación es continua e inapropiada, cuando se presentan fuera de sitio y la cantidad sobrepasa la cualidad (Galor y Hentschel, 2013). 
Díaz-Benjumea (2014) comenta:

El humor es para la autora un tipo de sublimación, pero uno particularmente interesante. Puede tener un aspecto no saludable, como en el caso de la necesidad constante de la broma para evitar el inevitable dolor de la vida, lo que ocurre en la personalidad de tipo hipomaníaca. Sin embargo, el humor maximiza nuestra capacidad de tolerar el dolor, y es defensivo en un modo positivo, a través de él se pueden contener el miedo al ridículo, ver las realidades duras con otra perspectiva, y ser capaces de reírse de uno mismo, lo que está en el mismo corazón de la salud mental. Su emergencia en un paciente previamente angustiado es frecuentemente la primera indicación de cambio interno significativo (párr. 72).

\section{El Trickster como imagen del humor}

Para Jung, un arquetipo es una fuerza que afecta la consciencia y las elecciones del individuo. Los arquetipos son partes del inconsciente y entran en conflicto con el yo y el pensamiento consciente. Los arquetipos dan forma al comportamiento humano $y$, en este sentido, un arquetipo se refiere a un patrón de comportamiento (Hietalahti, 2019).

La sombra es, como su nombre indica, la parte descuidada de la personalidad que, sin embargo, es una parte viva e influyente del inconsciente. Reconocer la sombra conlleva la aceptación de aspectos oscuros de la personalidad, y por tanto implica un considerable esfuerzo moral que genera resistencias.

Amir (2014), una de las pocas estudiosas del humor desde la perspectiva de Jung, indica que por medio a un proceso de autorreflexión se posibilita la comprensión del humor con respecto a las partes abandonadas de la personalidad. De ese modo, analizar la sombra profundiza en el descubrimiento de los aspectos psicológicos y sociales del humor y la risa (citado en Hietalahti, 2019).

La sombra, como emociones ocultas, inferiores o temidas, se encuentra en manifestaciones humorísticas como payasadas y chistes sucios. Cuando observamos de cerca lo que es divertido para nosotros comprobamos que hay manifestaciones activas de la sombra. Suele ser la parte de la sombra la que se ríe de los chistes (Hietalahti, 2019).

En el marco de referencia de Jung, la sombra y el humor son expresiones tanto individuales como sociales. En ese contexto, el humor puede ser ambos, rasgos superiores e inferiores de la humanidad. Enfrentarse a la sombra es necesario, pero también inquietante para un individuo.

El humor, incluso en su forma perturbadora, es valorado como algo bueno para los individuos y la sociedad porque maneja tabúes y temas delicados. Aunque debe tenerse en cuenta que no todo el humor es parte de la sombra, la visión junguiana sobre el humor y la risa admite que la sombra está presente en tipologías de risa que expresan aspectos negativos de la humanidad. En pocas palabras, la sombra funciona cuando la gente se ríe de cosas de las que no se debería reír.

La pregunta que Hietalahti (2019) postula es ¿quién hace reír a la sombra? Y la respuesta de Jung sería el Trickster, quien no es solo un fenómeno arcaico, sino un arquetipo que está presente en todos. Se fundamenta en la naturaleza paradójica de la psique humana, que de forma simultánea está llena de alegría y odio, así como de inclinaciones egoístas y altruistas. Esencialmente, el ser humano es un todo distorsionado. El desorden y la confusión alimentan el Trickster de Jung que desafía todo orden establecido (Hietalahti, 2019).

Jung explica que el Trickster es una suma de contradicciones. No tiene una forma fija, y es difícil dar una definición exacta para este arquetipo. Como 
recuerda Radin (1956) el Trickster es al mismo tiempo creador y destructor, dadivoso y negativo, el que engaña a los demás y que siempre se engaña a sí mismo. En todo momento está constreñido a comportarse como lo hace debido a los impulsos sobre los cuales no tiene control. No conoce el bien ni el mal, pero es responsable de ambos (citado en Hietalahti, 2019).

Como el Trickster no es una figura ni buena ni mala, tampoco es inmoral sino amoral, esta posición le permite confundir y sacudir las estructuras culturales y, por esta razón, es implícitamente una figura política (Hietalahti, 2019).

Desde la visión estética, el Trickster se configura como un ente alegre y libre de la humanidad. Esto quiere decir que ambas manifestaciones, a pesar de ser valores que se califican como positivos, tienen su parte oscura, ya que la alegría puede degenerarse en inconstancia e informalidad y la libertad en sometimiento e inmovilización. El Trickster engloba lo brillante y lo sombrío.

Esta figura no rechaza a nadie porque ocupan un lugar en la vida, el Trickster asume la vida sin prejuicios de modo completo y sin limitaciones. La risa va desde lo festivo, con la característica de relativizar las desigualdades culturales, sociales y económicas, hasta desarrollar una consciencia crítica que puede descender a una crítica descarada y corrosiva. Es capaz de desvelar la corrupción social exponiéndose a su propia humillación, malicia y degeneración moral para exponer la malicia de las sociedades (Manzanilla, 2016).

El Trickster es un agente de la anti-estructura. Así, su discurso puede afectar lo social a través de emplear medios poco ortodoxos y posiblemente subversivos. Se argumenta que la comedia y el humor pueden ofrecer reinterpretaciones del orden social que pueden perturbar esa estructura, debido a la similitud entre la limitación y la incongruencia humorística (Weaver y Mora, 2015).

\section{Identidad y humor dominicanos}

Tratar de definir qué es lo dominicano o la identidad dominicana, o sus rasgos, ha sido tema de variados estudios a lo largo de muchos ańos. El tema de la identidad suscita pasiones y desacuerdos sobre los atributos de la persona dominicana, que diversos estudios han revelado en sus indagaciones.

El fenómeno de la identidad dominicana está influenciado por el proceso de mestizaje que comenzó en la era colonial; mestizaje que era principalmente entre los africanos y blancos de origen español. Existe una inclinación de los sectores dominantes a asumir lo hispánico y negar lo africano. Puntualiza Zaiter (2000) que "para muchos dominicanos resulta difícil aceptarse como mulatos, mezcla negro-español" (párr. 6).

Otro aspecto definido por la autora, como característica que se refleja en el ser individual y colectivo dominicano, es la dependencia económica y cultural, que degrada la identidad dominicana. Igualmente, la existencia de estructuras sociales no fortalecidas y endebles, primando el autoritarismo (Zaiter, 2000).

La sociedad dominicana y sus pobladores tienden a manifestar sentimientos de infravaloración sobre sí mismos y a evaluar lo dominicano desde una visión negativa y pesimista, idea que es reforzada por los sectores dominantes. No obstante, entre las manifestaciones de los sectores populares se hace evidente la espontaneidad, el sincretismo religioso, la solidaridad grupal, la desconfianza como defensa, la constancia ante la vida, un "afán de vivir y vivir cada momento intensamente" (Zaiter, 2000, p. 17) y sentido del humor.

Fiallo y German (1994) con respecto a los conceptos de cultura, nación en identidad, desde la perspectiva sociohistórica, encontraron que el agrupamiento de características culturales populares se manifiesta en expresiones de una cultura 
del oprimido, que se afronta por medio a acciones de supervivencia que le permiten adaptaciones en medio de la opresión. La suspicacia como respuesta a las vivencias históricas se exterioriza con comportamientos de callar y observar, de modo tal que la persona puede tener tiempo para analizar o descubrir el gancho o trampa en el intercambio con otra persona. De ahí que la persona dominicana propende a guardar cierta información y a evitar la confrontación con los que están en el poder.

El sentido del humor como atributo dominicano es utilizado muchas veces como mecanismo de defensa, como una estrategia de mantener la dignidad arrebatada o poder tolerar el peso de la opresión. De ahí que la fiesta o festejar se realiza, a menudo, como modo de supervivencia y enmascara comportamientos de rebeldía. En ese sentido, el agravio se contrarresta con la risa o relajo. "Por eso el chiste, la música, los gestos se convierten en sátira y manifestación de libertad" (Fiallo y German, 1994, p. 55).

Zaglul (2011) con respecto al humor dominicano lo califica de seco y espasmódico, debido a que cada dominicano y dominicana tiene integrada dentro de su estructura lo desdichado del español y la tristeza del negro esclavo y a eso se le añade los avatares vividos a partir del descubrimiento. Afirma el autor que "somos fundamentalmente tristes. Nos alegramos por espasmo; solo en algunas ocasiones, muy raras por cierto" (p. 205). De ahí que este tipo de humor expresa una alegría breve que esconde lo afligido del estado emocional y mental de la persona.

Los individuos dominicanos poseen un sentido desmesurado de lo ridículo, y hacer reír al otro significa comportarse de manera ridícula. Como sociedad, se admite el chiste y se produce la risa cuando se está embriagado, porque se reduce el control de los pensamientos. Los comediantes dominicanos no son valorados como excelentes, pero tampoco como lo peores; esto quiere decir que, si nuestro comediante genera risa en las personas, por acciones subconscientes los individuos tienden a responder en su contra, ya sea ignorando su calidad artística o señalando algún defecto de su comportamiento privado. Señala Zaglul (2011): "Es una lucha entre alguien que nos quiere hacer reír y por el otro lado, alguien que no quiere reír. Si al fin lo logra, inconscientemente lo agredimos" (p. 205).

El chiste como lo maneja el dominicano es una payasada, una sandez, llegando a convertirse en una insolencia u ofensa, aunque el contenido del chiste no sea inmoral. El dominicano cuyo intercambio se caracteriza por ser chistoso es un individuo poco considerado y valorado. El chiste que comenta carece de espontaneidad y se refiere a lo que denominó Freud, el chiste equívoco o de alivio, cuya finalidad es liberar la tensión de algún conflicto interno (Zaglul, 2011).

En ese sentido, expone Zaglul (2011), que el dominicano no solamente es triste sino malhumorado, ya que su tristeza incluye irritabilidad, y este estado afectivo es bastante constante. La frase del argot popular coger cuerda alude a la tendencia de la persona de, frente a la mofa, responder con enojo. El individuo con quien se bromea responde en cortocircuito, es decir, es reactivo contra el que hace el chiste. En síntesis, las personas dominicanas cogen cuerda fácilmente.

Zaglul (2011) señala que el humor del dominicano expresa su tristeza y mal humor, lo que corresponde a una entidad mental llamada depresión. El dominicano y la dominicana están encajados en el universo de la tristeza irritable de la cual no se puede desligar y resulta en una depresión colectiva.

Pérez añade (1981) que “(...) nadie puede negar que este es un país donde continuamente se pone de manifiesto un humor seco y cortante en frases oídas al azar, en un piropo o en un apodo genialmente aplicado" (p. 9) que resulta, para la persona 
que lo recibe, en una experiencia con un matiz incisivo y brusco.

Ureña, Urbáez, Galiana y Oliver (2016) en su investigación Estilos de humor en universitarias dominicanas encontraron que en las adultas jóvenes dominicanas el humor preponderante era el agresivo y el autodestructivo o descalificativo. Este último se asocia con niveles moderados de depresión. Estos resultados evidencian el estilo pesimista y la tristeza del dominicano. En un artículo titulado Benéfico humor dominicano los artistas del humor criollo dicen inspirarse en la inclinación del dominicano a mofarse de sus desgracias y burlarse de la desdicha de los otros.

\section{Conclusiones}

En la configuración de los pobladores de la isla como grupo cultural y social se anticipaba un mélange socio-cultural interesante que todavía no ha sido integrado ni en el imaginario individual ni cultural dominicano. El fenómeno denominado taíno no fue culturalmente homogéneo ni heterogéneo, sino ambos al mismo tiempo. Esta propuesta alude a ese puente dialéctico que en términos de la identidad dominicana no se ha podido consolidar a través de los años, y el tema sigue siendo un concepto polarizado en lo particular y social de modo consciente e inconsciente.

La denominación Taíno a todos los habitantes de la isla demuestra, por un lado, cómo la historia de los indígenas fue construida desde la visión eurocéntrica, categorizando la diversidad de los grupos humanos existentes en ese momento desde el marco de referencia de los espańoles: para ellos todos eran Taínos. Por el otro, esa manera de documentar cómo era la sociedad, los modos de vida y la cultura de los taínos y demás grupos fue realizado desde la interpretación que los colonizadores espańoles hicieron de las experiencias, las costumbres y las manifestaciones de los taínos y demás grupos.
Los españoles ignoraron la cosmovisión de los grupos originarios, la descartaron como fuente de conocimiento para entender su cultura. Los cronistas españoles en sus escritos, muchos de ellos con cualidades de fantasía y exageración, registraron cómo era la vida de los grupos originarios usando únicamente el termino taíno. Por tanto, la historia contada proviene de la manera de percibir y conocer de los colonizadores, muy distinta a la de los nativos. Lo dicho se expresa claramente en una colonialidad del saber que perdura hasta nuestros días en las guías de aprendizaje, en las publicaciones académicas, en la cultura en general y en la autoimagen individual y colectiva de las sociedades, así como en los fines que los seres humanos pretenden alcanzar, y en un sinnúmero de elementos propios de la modernidad.

La colonización significó un cataclismo para los indígenas de la isla, que fueron despojados de sus tierras y de su vida cultural y religiosa, e implicó un cambio estructural en su sociedad y en su expresión cultural. En primer lugar, fueron sometidos a un proceso esclavista encubierto llamado la encomienda. Esto persistió hasta que quedaron pocos grupos indígenas en la isla y fue necesaria la importación de negros del África en calidad de esclavos para continuar con la empresa colonizadora.

Posteriormente, los indígenas fueron desarraigados de sus comunidades por medio de los repartimientos, lo que produjo rupturas en la vida de los clanes que afectaban a los lazos de índole afectivos, culturales y religiosos. Tenían, además, que pagar tributos y si no los pagaban a tiempo se incluían las demoras, lo que significaba aumentar la cantidad de trabajo o nuevos repartimientos. El trabajo forzado era la base de la empresa española en la búsqueda de oro y luego la caña. Este modo esclavista de trabajo generaba en los taínos extenuación física y debilidades que los llevaba a enfermarse y a morir por las enfermedades que habían traído los españoles. 
Estas condiciones infrahumanas se vieron agravadas por los conflictos bélicos en los que murieron miles de taínos, así como por el rapto y violación de las mujeres nativas ocupadas en la servidumbre o como esclavas sexuales. En el período del desarrollo de la caña de azúcar hubo raptos de mujeres indígenas por los esclavos negros cimarrones.

Todas esas manifestaciones de violencia eran incomprensibles para los taínos, ya que estos desconocían esos niveles de agresión, pues la estructura de sus relaciones sociales estaba basada en la amistad y en el acuerdo (aunque la mujer, en la cultura taína, era objeto de intercambio entre los poblados). Cabe destacar que después de los conflictos bélicos con otros grupos nativos de la isla o de otras islas, la paz se organizaba mediante los intercambios de regalos.

A los indígenas taínos les prohibieron los areitos, jugar a la pelota, aspirar cohoba y asearse en los meses de trabajo. Estas prohibiciones culturales y religiosas afectaban de manera significativa el equilibrio físico, emocional y cultural de las comunidades taínas. Toda esta estructura de la encomienda, el tributo y el trabajo forzado afectó a la cultura de los referidos grupos originarios y provocó el resquebrajamiento de su sociedad, pérdida del sentido, estados depresivos, suicidios, abortos y un desgano vital general.

La colonización se considera en primer lugar una experiencia traumática, ya que el maltrato, el ultraje, la violencia física y sexual, el despojo, las muertes y el cambio radical del estado de vida de los pobladores originarios, posiblemente los hizo experimentar miedo, desamparo, indefensión, pérdida del control de su vida, tanto en lo particular como en lo colectivo, y la continua sensación de estar en peligro, de poder ser aniquilados.

El proceso colonizador se ha considerado como un genocidio y como un trauma histórico, ya que ha generado daños emocionales y psíquicos que se han acumulado a través de generaciones. Las acciones ejercidas por los conquistadores amenazaban la integridad y la viabilidad de los grupos, su supervivencia, su cultura.

Este trauma histórico es debido a que existe una herida de conquista, subyugación y opresión. Se trata de una vivencia colectiva. Todos los grupos culturales de la isla padecieron un cambio sustantivo en sus identidades, ideales y modos de relación. Por tanto, los resultados del sojuzgamiento se han transmitido a otras condiciones políticas y sociales posteriores a la colonización. Las consecuencias mayores de esa experiencia intergeneracional ha sido la continua vulnerabilidad experimentada consciente o inconscientemente.

La colonización fue un acontecimiento horrendo que dejó marcas indelebles en los pobladores de la época, modificando significativamente su sentido de identidad, y también en los descendientes productos del mestizaje entre indígena, negro y español, lo que significa que también fue un trauma cultural.

Cuando el trauma es repetitivo, como lo fue el que provocó la colonización de la isla, se activan los llamados complejos culturales. Estos últimos alimentan más eventos traumáticos posteriores a la época histórica particular. Los complejos culturales se crean en las experiencias históricas repetitivas que se han grabado en la psique colectiva de las comunidades y en la psique individual de las personas que forman parte de esa colectividad.

Al ser la colonización un trauma cultural que activa los complejos culturales nos encontramos con el self cultural y sus defensas arquetípicas, las cuales son más profundas. Cuando un individuo tiene una experiencia traumática tiende a desarrollar defensas o resistencias que le permiten la adaptación.

Al ser considerada la colonización como un trauma cultural que se ha evidenciado en el desarrollo histórico de nuestra nación, caracterizada, además, 
por intervenciones extranjeras y varios procesos de dictadura, nos hace pensar en la defensa de la compulsión a la repetición de Freud. Esta defensa se caracteriza porque las personas o las colectividades permanecen enganchadas en conductas perjudiciales que les generan sufrimiento y parecen conducirlas a un futuro negativo, como el pesimismo y la pasividad del dominicano, característica de nuestra identidad.

El trauma individual y cultural es una experiencia que disocia a la persona o grupo para la adaptación; es decir, separa la experiencia traumática del consciente llevándola a la estructura inconsciente, por medio a la represión. De ahí que el trauma se activa cuando se confunde una situación del presente con los eventos que originaron el trauma.

La colonización como trauma histórico y cultural de modo concreto negó a los indígenas y a los negros, como colectividades, que pudieran ser reconocidos, comprendidos y valorados como seres humanos y culturas con una historia y un saber propio, lo que se denomina colonialidad.

El trauma de la colonización se expresa no solo en una colonialidad del poder y del saber, sino también del ser. Los grupos originarios y los negros fueron invisibilizados y tratados como entes no situados, no nombrados y sin cuerpo, eran un no-ser.

De ese modo, al no-ser, eran calificados como los condenados o damnés, un ser que no está ahí, cuya experiencia de vida estuvo enmarcada en una esclavitud despiadada, que los hacía experimentar una vivencia de muerte continua y fragmentada. Su cotidianidad era la confrontación constante de la muerte, de ahí que se transformaba en un suceso ordinario. La colonialidad del ser entonces se convierte en la normalización de estas circunstancias excepcionales de peligro de muerte, de miedo a la aniquilación que es lo que acontece en un trauma. En ese sentido, la invisibilización y la deshumanización son manifestaciones básicas de la colonialidad del ser.

La colonización como proceso opresor instaura la diferenciación de los individuos en grupos clasificados como: dominante-dominado, superior-inferior y opresor-oprimido. Estos esquemas afectivos, cognitivos y comportamentales se introyectaron en la psique individual y colectiva de los pobladores originarios y sus descendientes.

Existe una estrecha relación entre la opresión, la opresión internalizada y la colonización, ya que el proceso colonizador fue la entrada impuesta por los españoles al territorio para explotarlo, así como a los pobladores. Luego implantaron su cultura y desintegraron la cultura nativa, valorándola de inferior o salvaje; posteriormente el colonizador educa al colonizado categorizado como incivilizado, de ahí que la tiranía y la dominación, es decir, se instaura la opresión y, por último, se establecen instituciones colonizadoras que perpetuaban la superioridad del colonizador.

Esta opresión internalizada se hace presente en la vida de la dominicana y del dominicano post-colonización por medio a la pasividad, el comportamiento de dependencia, la sospecha, el despotismo, la violencia, la infravaloración como sociedad, la inseguridad en nosotros mismos, la apatía para la tarea del pensar, el paternalismo y la emulación de paradigmas de la transculturación.

El trauma individual posee una estructura inconsciente daimónica que se explica a partir de una fragmentación de las defensas del yo, que para poder mantenerse y no desintegrarse frente a la situación de peligro activa una imagen daimónica que proviene de la psique colectiva.

Para la persona poder desarrollar su vida, después de una vivencia traumática, a nivel inconsciente emerge una figura daimónica que tiene una doble 
función, por un lado, es un guardián que protege, y por otro lado es un personaje persecutorio que se encarga de mantener el trauma fijo como un monolito que no interrumpa la vida consciente de la persona.

A esta estructura funcional inconsciente se le denomina el sistema de autocuidado, que crea la persona para lidiar con la experiencia traumática y que puede considerarse que sucede igual a nivel grupal.

La figura daimónica en el trauma individual y cultural encapsula la parte frágil o vulnerable de la persona, la cual es separada de la realidad para evitar ser violentada o traumatizada nueva vez. Otras veces este ser daimónico es un ángel guardián que calma y protege internamente la parte infantil del self.

Esta alternancia de funciones acompañada de la imagen del niño interior u otra figura vulnerable, al unificarse constituyen lo que se denomina sistema de autocuidado arquetípico que tiene la función de proteger y resguardar el espíritu personal y colectivo del self autentico, tanto de una persona como de una colectividad.

En esta estructura, la figura daimónica permite la adaptación, mas no así la integración, por lo que la persona y la cultura siguen perpetuando la estructura traumática. Para el caso dominicano, la colonización como trauma cultural activa el sistema de autocuidado colectivo, entonces la figura daimónica se queda polarizada siendo muchas veces persecutoria.

Esta figura como defensa arquetípica es el Trickster con su manifestación en la sombra, es decir aquel que usa el humor para desestabilizar, dominar, burlarse, ocultar lo propio, divertirse, tener placer e imponerse. Este Trickster dominicano manifiesta, la mayoría de las veces, un humor agresivo, caracte- rizado por el sarcasmo, burlas, ridiculización, denigración, menosprecio y manipulación. $Y$ a veces el humor autodestructivo que es auto-peyorativo, y divierte a los demás por medio de chistes o acciones graciosas a expensas de sí mismo, ridiculizándose o subestimándose para obtener el reconocimiento de los otros. A su vez, es una negación defensiva o vía para ocultar los afectos. Lo que confirma la opresión internalizada fijada desde los tiempos de la colonia.

El chiste, la mofa y el humor corrosivo son respuestas conscientes de motivaciones inconscientes que son comunes; como una forma de oprimir a otro miembro del mismo grupo en la imposibilidad de aceptar su propia opresión.

El Trickster dominicano usa el humor agresivo como un alivio, pero también como una forma de imponerse sobre el otro, replicando en la cotidianidad la estructura opresor-oprimido, conquistador-conquistado, colonizador-colonizado, introyectada en una psique individual y colectiva patriarcal donde las soluciones basadas en el amor y la no violencia se asocian a lo femenino o maternal, de manera tal, que son satirizadas y menospreciadas. El humor agresivo es un manifestación patriarcal y ofensiva que en la psique corresponde a una tendencia a admirar el poder y a subestimar la debilidad y la victimización. De esa manera, el humor espasmódico dominicano, que es triste e irritable, es la forma consciente de la figura daimónica del Trickster, es decir, de todo lo negado, lo reprimido, lo escindido del trauma cultural dominicano que se encuentra en la sombra.

Por consiguiente, cuando la sombra se activa, la personificación daimónica del Trickster aparece para mantener el sistema de autocuidado inconsciente, que a nivel de la consciencia se expresa en la suspicacia del dominicano y dominicana y en creer que toda relación entre las personas o grupos está matizada por un gancho o trampa. 
El Trickster es impulsivo, por eso cuando se presenta en el contexto dominicano expresa el chiste que está fuera de lugar, o es una necedad o una payasada. El Trickster es un bufón que se auxilia de la risa, que no solo indica lo divertido o cómico de sus tretas y artimañas, sino que demuestra algo complejo y profundo, para nuestro caso el opresor internalizado fijo y rígido que mantiene el sistema de autocuidado. El Trickster dominicano es el daimón persecutor, el colonizador, el que oprime a otro a través del chiste agresivo.

El Trickster cuando encarna el humor agresivo transgrede los límites, por eso los chistes que contienen microagresiones, si se hacen de manera continua, manifiestan un acto de opresión que se puede convertir en opresión internalizada. El Trickster dominicano con el humor agresivo establece un relación de poder, se defiende de la herida cultural colonial y otras posteriores y transforma toda experiencia humana, no importa la cualidad, en un chiste y un relajo que no permite ni la manifestación de los afectos relacionales, ni la integración de experiencias dolorosas a lo consciente, manteniéndose a nivel inconsciente polarizado con el daimón persecutor que se hace consciente al burlarse de sus propios infortunios pero, sobre todo, de la desventura de los demás.

El humor agresivo de las dominicanas y los dominicanos es manifestado en la figura daimónica del Trickster, es una defensa inconsciente patológica, que mantiene el sistema de autocuidado inconsciente grupal activo, lo que trae como consecuencia la no integración de las experiencias dolorosas inconmensurables del proceso colonizador. El Trickster en su expresión consciente a través de la burla, el chiste nocivo y la emocionalidad superficial perpetua una experiencia del self individual y colectivo fragmentado, que no puede ser incorporado a la vida consciente por lo tanto perdura como un constante pretexto del trauma histórico y cultural de la colonización.

\section{Referencias}

Álava M.A y Álava, J.L (2018). Los Mecanismos de defensa: una comparación teleológica entre Sigmund y Anna Freud. Perspectivas 1(14), $1-12$.

Alexander, J.C. (2016). Culture trauma, morality and solidarity: The social construction of 'Holocaust' and other mass murder. Thesis Eleven 132(1), 3-16. Doi: 10.1177/0725513615625239

Amici, P. (2019). The Humor in Therapy: The Healing Power of Laughter. Psychiatria Danubina, 31(3), 503-508. Recuperado de http:// www.psychiatria-danubina.com/2019-vol31-sup-3

Besser,A.,Weinberg,M.,Zeigler-Hill,V.,Ataria,\&Neria, Y. (2015). Humor and Trauma-Related Psychopathology Among Survivors of Terror Attacks and Their Spouses. Psychiatry, 78, 341-353. Doi: 10.1080/00332747.2015.1061312

Boerner, M, Joseph, S, \& Murphy, D. (2017). The Association Between Sense of Humor and Trauma-Related Mental Health Outcomes: Two Exploratory Studies. Journal of Loss and Trauma 22(5), 440-452. Recuperado de http://dx.doi.org/10.1080/15325024.2017. 1310504

Carvallo, E. (2012). A Region Split by its Cultural Complexes. In P. Amezaga, G. Barcellos, A. Capriles, J. Gerson \& D. Ramos (eds.). Listen to Latin America: Exploring Cultural Complexes in Brazil, Chile, Colombia, Mexico, Uruguay and Venezuela. New Orleans, Louisana: Spring Journal Book.

Cassá, R. (1974). Los tainos de La Española. Santo Domingo, República Dominicana: Publicaciones de la Universidad Autónoma de Santo Domingo, Volumen CLXV.

Castro-Gómez, S. (2007). Michel Foucault y la colonialidad del poder. Tabula Rasa, Revista de Humanidades 6, 153-172. Recuperado de https://www.redalyc.org/ pdf/396/39600607.pdf 
David, E.J.R. \& Derthick, A.O (2014). What is Internalized Oppression. In E.J.R. David (ed.). Internalized Oppression: The Psychology of Marginalized Groups. New York: Springer Publishing Company.

David, E.J.R. \& Derthick, A.O. (2018). The Psychology of Oppression. New York: Springer Publishing Company.

Díaz-Benjumea, L.J. (2014). Diagnóstico Psicoanalítico. Comprender la estructura de personalidad en el proceso clínico (McWilliams, N.). Apertura psicoanalitica, Revista Internacional de Psicoanálisis 47. Recuperado de https://aperturas.org/articulo.php?articu$\mathrm{lo}=0000852 \& \mathrm{a}=$ Diagnostico-Psicoanalitico-Comprender-la-estructura-de-personalidad-en-el-proceso-clinico-McWilliams-N

Domínguez, J. (2006). Historia Dominicana. Santo Domingo: Letra Gráfica Breve.

Duran, B., Duran, E \& Yellow Horse Brave Heart, M. (1998). Native Americans and the Trauma History. In R. Thornton (Ed) Studying Native America: Problems and prospects in Native American studies, Chapter: Native Americans and the trauma of history. United States of America: University of Wisconsin Press.

Etchegoyen, H., Kargieman, A. et al. (2005) El concepto de trauma según diferentes autores psicoanalíticos. Revista de Psicoanálisis APdeBA 27(1-2), 181-259. Recuperado de https:// www.apdeba.org/revista-psicoanalisis/

Fiallo, J.A. y German, A. (1994). Cultura, nación e identidad en los Procesos históricos dominicanos. PNUD-SEEBAC (Eds). Cultura, Educación, Ciencia y Construcción del Conocimiento. Santo Domingo, República Dominicana: Editora Taller.

Galor, S. y Hentschel, U. (2013). El uso de los mecanismos de defensa como herramientas de afrontamiento por veteranos israelíes deprimidos y con TEPT. Subjetividad y Procesos Cognitivos 17(1). 201-133. Recuperado de https://www. redalyc.org/pdf/3396/339630261005.pdf
Gómez, S. (2016). Estudio de caso: La incidencia de la traumatización severa en las representaciones maternas (Tesis de maestría). Universidad Alberto Hurtado, Santiago de Chile. Recuperado de http://repositorio.uahurtado. cl/handle/11242/8078

Gómez-Quintero, J.D. (2010). La colonialidad del ser y del saber: la mitologización del desarrollo en América Latina. El Ágora USB Revista de Ciencias Sociales 10(1), 87-105. Recuperado de https://revistas.usb.edu.co/ index.php/Agora/article/view/366

Hawkeye-Robertson, LL. (2015). The Trauma of Colonization: A Psycho Historical Analysis of One Aboriginal Community in The North American North West Interamerican. Journal of Psychology (IJP) 49(3), 317-314. Recuperado de https://www.redalyc.org/ pdf/284/28446020003.pdf

Hietalahti, J. (2019). Carl Jung and the Role of Shadow and Trickster in Political Humor: Social Philosophical Analysis. In C. P. Martins (ed.). Comedy for Dinner and Other Dishes (pp. 20-41). Instituto de Estudios Filosóficos (IEF).

Hipólito-Delgado, C., Gallegos-Payan, S. \& Baca, T.I. (2014). Self-hatred, Self-Doubt, and Assimilation in Latina/o Communities: Las consecuencias de la colonización y opresión. In E.J.R. David (ed.). Internalized Oppression: The Psychology of Marginalized Groups. New York: Springer Publishing Company.

Inoa, O. (2018). Historia Dominicana. Santo Domingo, República Dominicana: Letragráfica.

Jiang, T., Hao, L. \& Hou, Y. (2019). Cultural Differences in Humor Perception, Usage and Implications. Frontier in Psychology 10(123), 1-8. Doi: 10.3389/fpsyg.2019.00123

Kalsched, D. (1996). The Inner World of Trauma. Archetypal Defenses to the Personal Spirit. New York: Routledge. 
Kirmayer, L.J., Gone, J.P. \& Moses, J. (2014). Rethinking Historical Trauma. Transcultural Psychiatry, 51(3), 299-319.

Maldonado-Torres, N. (2007). Sobre la colonialidad del ser: contribuciones al desarrollo de un concepto. En S. Castro-Gómez y R. Grosfoguel (eds.). El giro decolonial reflexiones para una diversidad epistémica más allá del capitalismo global. Bogotá, Colombia: Siglo del hombre editores.

Mandacarú-Guerra, M.H. (2018, agosto). Sombra y Humor. Conferencia presentada en el VII Congreso Latinoamericano de Psicología Junguiana. Bogotá, Colombia.

Martin, R.A., Puhlik-Doris, P., Larsen, G., Gray, J. \& Weir, K. (2003). Individual Differences in Uses of Humor and Their Relation to Psychological Well-Being: Development of The Humor Styles Questionnaire. Journal of Research in Personality 37, 48-75. Recuperado de https://www.sciencedirect.com/science/ article/abs/pii/S0092656602005342

Manzanilla Sosa, S.A. (2016). La dimensión ética y estética de la figura del Trickster en la literatura. Valenciana, 9(18), 241-270. Recuperado de http://www.scielo.org.mx/scielo.php?script=sci_ arttext\&pid=S2007-25382016000200241\&l$\mathrm{ng}=\mathrm{es} \& \mathrm{t}$ lng=es

Minaya, J. (2014). Pedro Francisco Bono, vida, obra y pensamiento crítico. República Dominicana: Archivo General de la Nación.

Mira-Caballos, E. (2017). Revisando el viejo debate del colapso de los taínos. Clío, 17, 284-335. Recuperado de: http://www.academiadominicanahistoria.org.do/index.php/ revista-clio/

Nieto-Martínez, I. y López-Casares, M.C. (2016). Abordaje integral de la clínica del trauma complejo. Clínica Contemporánea 7(2) 87-104. Doi: http://dx.doi.org/10.5093/cc2016a

Paivio, S.C \& Pascual-Leone, A. (2010). Emotion-Focused Therapy por Complex Trauma: An Integrative Approach. Washington, DC: American Psychological Association.
Pérez, M.E. (1981). Estampas dominicanas. Santo Domingo, República Dominicana: Publicaciones América, S.A.

Quijano, A. (2014). Colonialidad del poder, eurocentrismo y América Latina. En A. Quijano (Ed) Cuestiones y horizontes: de la dependencia histórico-estructural a la colonialidadldescolonialidad del poder. Buenos Aires: CLACSO.

Robiou-Lamarche, S. (2016). Tainos y Caribes. Las culturas aborigenes antillanas. San Juan, Puerto Rico: Editorial Punto y Coma.

Saldaña-García, J. (2014). Trauma, personalidad y resiliencia. Una visión aproximada desde la Psicoterapia breve integrada. Sociedad Española de Medicina Psicosomática y Psicoterapia 4(3), 1-28. Recuperado de https://www. psicociencias.org/revista/resultados.php

Schere, M.J. (2017). Los matices del humor en Platón y Aristóteles y su proyección sobre la comedia de Aristófanes. Florentia Iliberritana Revista de estudios de Antigüedad Clásica 28, 211-222. Recuperado de https://revistaseug.ugr.es/index.php/florentia/article/ view/6712/5832

Singer, T. (2006). The Cultural Complex: A statement of the Theory and its Application. Psychotherapy and Politics International, 4(3): 197-212. Doi: 10.1002/ppi.110

Stamm, H.B., Stamm, H.E., Hudnall, A.C. \& Higson-Smith, C. (2004) Considering a theory of cultural trauma and loss. Journal of loss and trauma, 9(1), 89-111. Doi: 10.1080/15325020490255412

Ulloa-Hung, J. (2014). Arqueología en la línea noroestes de La Española. Paisajes, Cerámicas e Interacciones. Santo Domingo, República Dominicana: Instituto Tecnológico de Santo Domingo.

Ureña-Ramírez, AJ., Urbáez-Echavarria, NJ., Galiana-Llinares, L. y Oliver-Germes, A. (2016). Estilos de humor en universitarias dominicanas. Revista Búsqueda, 3(17),191-201. Doi https://doi.org/10.21892/01239813.288 
Veira, J.L. (2018). Las teorías del humor y el cambio cultural. Revista Oficial de la

Sección de Psicología y Salud del COPG, 11, 9-20. Recuperado de

https://copgalicia.gal/system/files/PDFs/publicacions/anuario_numero_11.pdf

Weaver, S. \& Mora, R.A. (2015) Introduction: Trickster, humor and activism. Internacional Journal of Culture Studies, 19(5), 479-485. Recuperado de https://doi. org $/ 10.1177 / 1367877915595302$

Weiusstub, E. \& Galili-Weisstub, E. (2004). Collective Trauma and Cultural Complex. In T. Singer \& S.L. Kimbles (eds.). The Cultural Complex. Contemporary Jungian Perspectives on Psyche and Society. New York: Routledge
Zaglul, A. (2011) Obras Selectas, Tomo I. Archivo General de la Nación CXXXI. Santo Domingo, República Dominicana: Archivo General de la Nación y el Programa Cultural Banco de Reservas

Zaiter, J. (2000). Un análisis psico-social de la identidad dominicana. Perspectivas psicológicas 1. Recuperado de https://es.scribd. com/document/137171241/Un-analisis-psicososial-de-la-identidad

Zoja, L. (2004). Trauma and abuse: the development of a cultural complex in the history of Latin America. In T. Singer \& S.L. Kimbles (eds.). The Cultural Complex. Contemporary Jungian Perspectives on Psyche and Society. New York: Routledge.

\section{Datos de filiación}

Patricia Liranzo. Psicóloga clínica del Grupo Profesional Psicológicamente (GPP), profesora e investigadora del Área de Ciencias Sociales y Humanidades del Instituto Tecnológico de Santo Domingo (INTEC) desde el año 2011. Posee una maestría en Filosofía Global de la Universidad del País Vasco UPV/EHU, una maestría en Psicología Clínica por la Universidad Autónoma de Santo Domingo y licenciatura en Psicología por el Instituto Tecnológico de Santo Domingo INTEC. Sus áreas de investigación son Psicología Clínica, Psicología Educativa y Educación. 